\begin{tabular}{|c|c|}
\hline \multirow{3}{*}{ 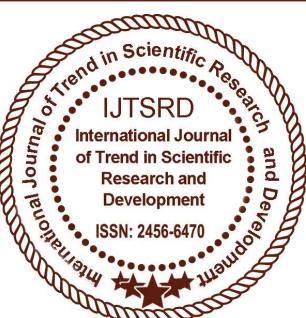 } & $\begin{array}{l}\text { International Journal of Trend in Scientific } \\
\text { Research and Development (IJTSRD) }\end{array}$ \\
\hline & International Open Access Journal \\
\hline & ISSN No: 2456 - 6470 | www.ijtsrd.com | Volume - 2 | Issue -3 \\
\hline
\end{tabular}

\title{
Diamond shape model Advanced model of Service triangle
}

\author{
Dr. Teena Mishra \\ Asst. Professor, MBA \\ Patel Group of Institutions, Bhopal, Madhya Pradesh, India
}

\begin{abstract}
\end{abstract}
Due to increasing competition services are the main focus of marketers. Organizations are not satisfied just by selling products, but also to provide better service. For this they strive continuously. There are three types of marketing 1) External marketing 2) Internal marketing 3) Interactive marketing. Internal marketing is a new realm of marketing in this arena that connects all types of marketing. Internal marketing represents an exchange between the organization and employees, interactive marketing is the exchange process between staff and customers, and external marketing is the exchange process between the organization and external customers. Groonroos defined interactive marketing in a well manner. But due to increasing fierce competition, global environment, and dynamic work environment, internal marketing become important in the organization. Internal marketing emerged from service marketing concept. Various researchers found internal marketing as a solution to improve service quality. Thus, it is necessary to understand all types of marketing and what is the relation between them. This paper emphasized on the service model of marketing. Employees (internal customers), external customers and organization, are the three important players of the model. There is an exchange process between all of them to fulfill their goal. The new diamond model is prepared in this paper which clears those employees (internal customers) and external customers are equally important for the organization. Interactive marketing plays a vital role for the internal customers as well as external customers. By this organization developed a strong relationship with customers to achieve their goal.
Keywords: Internal marketing, service model, interactive marketing

\section{INTRODUCTION}

In eighties TQM (total quality management) has been started to improve organizational performance and growth. Many organizations utilized this by implementing it by team management, directly linked performance with reward, promotions, and training, etc. TQM is an important concept to get better organizational efficiency and to improve product quality. Various companies used it fruitfully are Ericson Inc. of Lynchburg, AT and $\mathrm{T}$ wireless services, Champion International Corporation's paper, and wood pulp products plant operations, Xerox, Ford, General motors' etc. The modern concept of TQM is to give customer satisfaction.

Internal marketing originated as a solution to improve service quality in nineteen eighties. The rationale behind the principle of internal marketing is to motivate and satisfy internal customer first. In this respect Wildes (2005), stated that increasing internal service quality resulted in higher employee satisfaction, reduced employee turnover, improved image of the organization, etc [1].Service quality is a very common concept in the business realm while internal service quality is an emerging concept in internal marketing. Internal marketing is to improve interaction and satisfaction of internal customers for organizational growth. Internal customers play a vital role in increasing production, performance and service excellence of the organization.[2] 
International Journal of Trend in Scientific Research and Development (IJTSRD) ISSN: 2456-6470

\section{LITERATURE REVIEW}

\section{A. Types of marketing}

Service marketing is a 'game of promise'. In the service transaction, there are three types of marketing-

1) External Marketing- External marketing makes a promise to customers for giving benefits, satisfaction by way of advertising, public relation, exercises and others.

2) Internal Marketing-This marketing is for service providers. The organization provides equipment, computers, telephones working space to internal customers. They are employees, channel partners, and franchises. An organization has to recruit, train, motivate, to improve service quality. The focus is on motivation and satisfaction of employees to improve service quality.

3) Interactive Marketing- The providers interact with the customers. Provider plays an important role in making images of the organization.

They satisfy external customers by keeping promises of their organization. [3]

Fig. no. 1 shows three types of marketing:-

1) Enterprise does marketing with an external customer that is external marketing.

2) Enterprise does marketing with a staff that is internal marketing.

3) The staff does marketing with an external customer that is interactive marketing.

With this service triangle model focus on the external customer is from two sides, one from enterprise side and second from the staff side.

The focus of staff towards the external customer is to improve service quality.

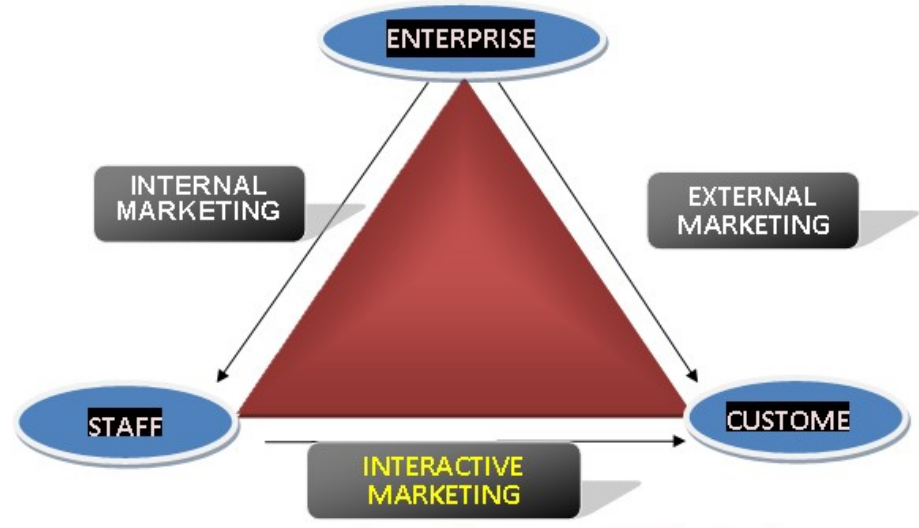

Fig.1 Service triangle Model

Staff interacts with an external customer is called interactive marketing. Before doing interactive marketing, there is, need to do internal marketing first.[4]

In figure 2., there are two sub-processes, which are focusing towards external customers. Both the subprocess occurs simultaneously towards external customers.

\section{B. Two sub-process of enterprise towards external customers}

1) Sub-process 1-Enterprise starts internal marketing with staff and staff doing interactive marketing with external customers.

2) Sub-process 2-Enterprise starts external marketing with external customers.

These above two sub-processes of this model focus towards external customers. Enterprise does two types of marketing that are internal marketing and external marketing. The staff does interactive marketing with external customers. The exchange process between enterprise and external customer is for mutual satisfaction. The staff isn't suddenly jumping towards the external customers. For doing external marketing enterprise required staff to do interactive marketing. Therefore, the enterprise is working towards two directions for external customers. 


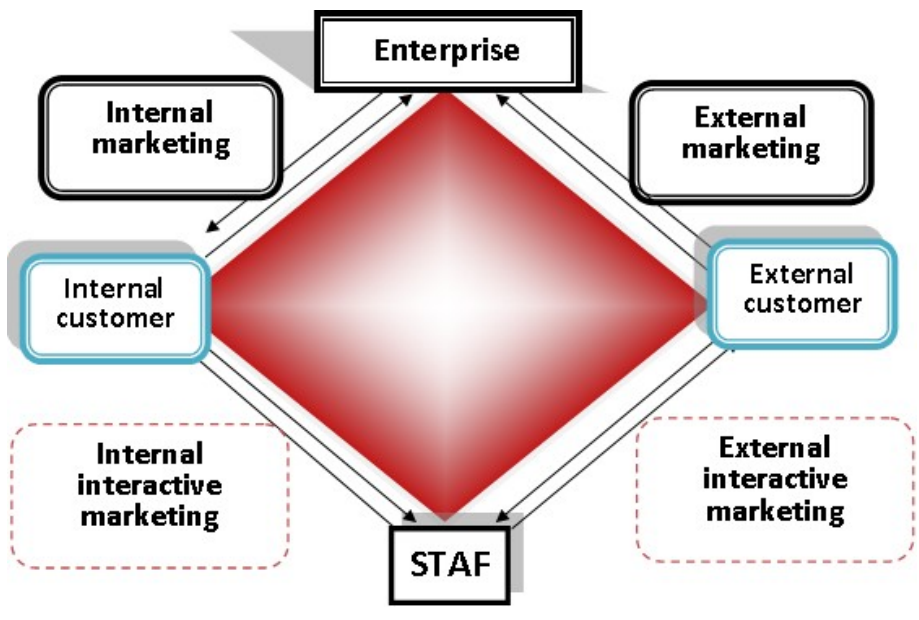

Fig. 2: New Diamond of service marketing

The new Diamond shape models shown in figure 2 create the importance of internal customers. Just as external customers have a need and desire to fulfill it in the same way internal customers also have the desire, need to satisfy it.

\section{Two sub process of the Diamond shape model}

\section{- Process 1}

a) Sub-process 1-

Enterprise starts first to understand the need and desire of its employees. Thus, internal marketing first starts with the organization between enterprise and internal customers.

Figure 2. This diamond service-marketing diagram indicates that interactive marketing is the need of not only for external customer but also for internal customers. Internal customers interact in the internal market place. Enterprise directly influences internal customers that are internal marketing and employees interact with each other that are interactive marketing. b) Sub-process 2-

In the organization, every internal customer interacts with other internal people. To keep the promise of the organization this interactive marketing within the organization plays a vital role.

Thus new diamond model is more advanced model then service triangle model. In this competitive era there is need of diamond model of service marketing.

\section{CONCLUSION}

Internal marketing is the growing concept. Thus it is necessary to think about all types of marketing and the link between them. Marketing is not a new concept but who are the participants makes the difference between all types of marketing. We are in the relationship era, thus it is necessary to improve all types of marketing. Service triangle model of Groonroos is very vital to improve service quality of the organization. Due to increasing awareness of internal marketing it becomes necessary to think about internal marketing concept. Thus this research paper gives importance to the internal interactive marketing and external interactive marketing to improve the service quality of the organization.

\section{REFERENCES}

1) Wildes, V. (2005). 'Internal service quality: marketing strategies can help to reduce employee turnover for food servers.' International journal of hospitality and tourism administration 6 (2), pp. $1-27$ the 'triangular shape of service marketing' diagram to 'diamond shape' diagram of service marketing. 
2) Cal Shaohan (2010). 'Examining the relationship between internal service quality and its dimensions and internal customer satisfaction' Total quality management, Routledge, Vol. 21, No. 2, pp. 205-223.

3) Bhattacharya, C. (2009). Services marketing. Excel Books India.

4) Bellaouaied Myriam and Gam Abdelkader (2011), "Internal marketing as a new alternative for the service employees' performance: An Empirical study." U.A.S. Revista de Communicare si Marketing. p 139-160.

5) Berry, L. L. (1981). The employee as customer. Journal of retail banking, 3(1), 33-40.

6) De Farias, S.A., 2010. Internal Marketing (IM): a literature review and research propositions for service excellence. BBR-Brazilian Business Review, 7(2), pp.99-115.

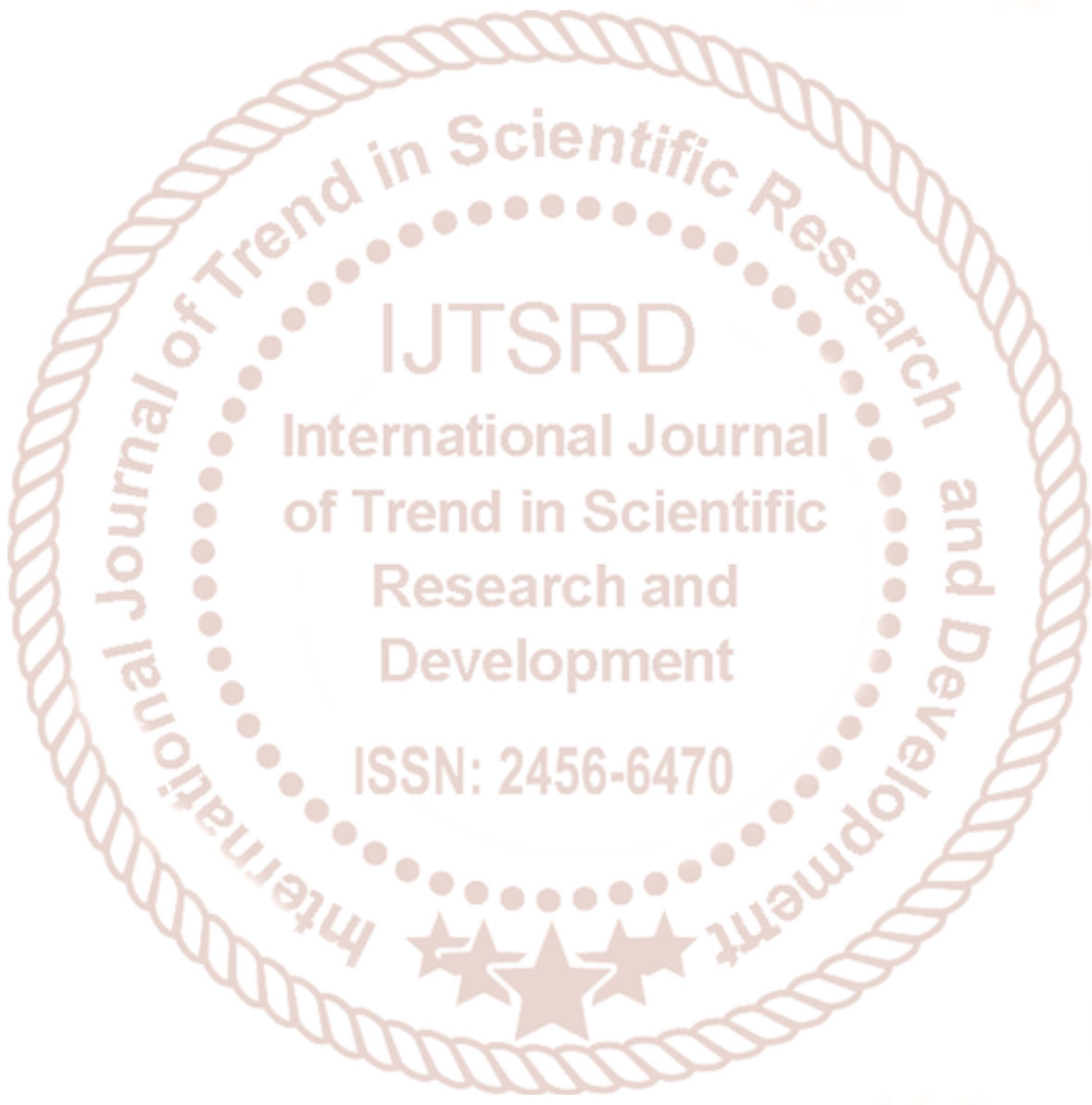

